\title{
OMENA, L. M.; FUNARI, P. P. A. (Orgs.). As experiências sociais da morte; diálogos interdisciplinares. Jundiaí: Paco Editorial, 2017. 244 p.
}

Tais Pagoto Bélo ${ }^{1}$

O livro As experiências sociais da morte: diálogos interdisciplinares inicia com nada menos que um poema de Aphonsus de Guimaraens que descreve o suicídio de Ismália de uma forma quase transcendental e surreal. Escolhido com sensibilidade e sutileza pelos organizadores desta coletânea de capítulos, Luciane M. de Omena, professora doutora da UFG, e Pedro P. A. Funari, professor titular da Unicamp, esse poema demonstra, já no início da leitura, o quanto a morte é uma das concepções mais misteriosas da vida e dos sentidos humanos. O seu medo e caráter simbólico sempre estiveram presentes em diferentes culturas, tempos e lugares.

Nessa perspectiva, no prefácio, de forma complementar, Renata Senna Garraffoni, professora doutora da UFPR, inicia seu texto com a Marcha Fúnebre (Em memória de um camarada da juventude), de Herman Hesse (1956), em que o autor deposita os sentidos humanos diante da perda, da angústia do espírito e, principalmente, da memória, que não lembra apenas do morto, mas que naquele momento a música passou a influenciar os mecanismos cognitivos da lembrança, atenuando todos os mesmos sentidos da consternação da morte quando ouvida posteriormente. Garraffoni descreve o livro como inquietante, porque trata de um assunto considerado tabu. Conforme essa autora menciona, a morte é algo que leva ao desconhecido e, por esse motivo, não se pensa nela como parte da experiência cultural humana.

Inspirada pela visita feita ao cemitério Recoleta, de Buenos Aires, Luciane M. Omena dá início à apresentação da obra, entre túmulos e lápides, percebendo o "quanto o mundo dos mortos se entrelaçava ao mundo dos vivos" (Omena, 2017: 15). Tal motivação a levou a estudar a simbologia da morte e a desenvolver um doutorado, na Unicamp, com o Prof. Funari, intitulado Memória e luto: a simbologia da morte no logos

\footnotetext{
${ }^{1}$ Pós-doutoranda, CNPq, Universidade Estadual de Campinas - Campinas, Brasil. email: taispbelo@gmail.com
} 
filosófico de Lúcio Aneu Sêneca em diálogo com os vestígios materiais (27 a.C. - 68 d.C.), com apoio da FAPEG/CAPES. Esse trabalho possibilitou a ideia para a construção da obra aqui referida, a qual abarca perspectivas interdisciplinares, fontes materiais e documentais, explora diversos momentos históricos e engloba os significados, efeitos e mecanismos sociais diante da morte.

Essa obra é dividida em duas seções: a primeira, morte e memória nas sociedades mediterrâneas, envolve trabalhos como o de Ana P. Pinto, professora doutora da Universidade Católica Portuguesa, intitulado No limiar da morte: Homero, que trabalhou com a Ilíada e a Odisseia, demonstrando como Homero, com a Guerra de Troia, propõe questionamentos sobre a morte através do cenário bélico, dos funerais de Heitor e por meio da própria memória, utilizada como estratégia reformuladora do presente. A autora também destaca a função da mitologia como transgressora da fronteira entre a vida e a morte, a consciência da morte de Aquiles, a fugacidade da vida, a mortalidade e a morte criminosa de Agamémnon.

Além disso, Luciane M. Omena e Pedro P. A. Funari apresentam $O$ ridículo de um funeral: a simbologia da morte na sátira 'Apocolocyntosis' de Sêneca, em que iniciam comentando a respeito do fim do corpo biológico e de que este é capaz de criar significados individuais e coletivos, caracterizando-se como uma experiência social que junto com a morte formam construções históricas, as quais assumem papéis culturais. Os autores se apoiam no estudo das representações funerárias a partir da sátira menipeia Diui Claudii Apocolocyntosis e assinalam que os funerais eram como espetáculos de poder no império romano, colocando assim em relevância a análise da procissão funerária e seu desenrolar no espaço urbano, os quais enfatizavam o morto e sua posição diante de gerações familiares, tornando sua memória algo público e doméstico.

Para finalizar esse primeiro momento, Cláudio U. Carlan, professor doutor da UNIFAL, escreve sobre $A$ representação da morte nas moedas de Constantino, evidenciando como as moedas, com a imagem do rosto de Constantino I, representaram seu poder até mesmo depois de sua morte, continuando sua circulação até a invasão muçulmana, no século VIII.

A segunda parte da obra, intitulada Morte e Arqueologia sob o viés Moderno e Contemporâneo, apresenta maior diversidade de tempo e lugar. Ela é iniciada por Claudia Rodrigues, professora doutora da UNIRIO, com o capítulo As experiências da morte no Rio de Janeiro colonial, 
em que expõe como a Igreja Católica, agindo em concordância com o lado lusitano, utilizou da morte para a catequização de novos fiéis, além de evidenciar a cultura funerária de indígenas e africanos. Logo após, Louise P. Alfonso, professora doutora da UFPel, e Jaciana M. G. Araújo, antropóloga pela UFPel, mestre e doutora em psicologia pela UCPel, em A morte, o morrer e o papel social da arqueologia na sociedade contemporânea, abarcam a função da arqueologia para o debate acerca da morte e da desconstrução sobre o tabu de não se falar a seu respeito. As autoras fazem um apanhado psicológico em relação ao luto que abrange a depressão e a ansiedade. Ainda, mostram a dificuldade de lidar com as crianças no que concerne a esse tema e como a educação patrimonial pode ajudá-las a compreender melhor o assunto.

Maria E. Borges, professora doutora da UFG, escreve a respeito da contemporaneidade artística dos túmulos e cemitérios no Brasil em Um olhar indagador sobre os cemitérios: as representações modernas da morte. A autora percebe padrões europeus que possibilitaram uma vasta amostragem artística para o público, o simbolismo iconográfico e expressões de sentidos universais, como dor, prazer e amor, além de outros aforismos sobre a morte. Ressalta que o poder público pode promover uma hierarquização dos museus pela monumentalização e que estes passam a ser os cemitérios-museus. Além disso, nota que a estrutura dos cemitérios deve permitir incluir conceitos de morte, relações com a morte e diversos rituais fúnebres para que o público possa vivenciá-la. Nessa perspectiva, a autora não deixa de realizar uma análise da arte em túmulos de diversas partes do mundo.

Seguindo a questão da arte funerária, como no capítulo passado, Flávia R. Marquetti, pesquisadora doutora do Grupo de Pesquisa Arqueológica Histórica da Unicamp, questiona como prender em uma imagem simbolismos tão subjetivos como a morte, sentimentos para lembrar o ausente e a finitude da vida, analisando-os, por exemplo, por meio do uso das plantas nas celebrações da morte. Nanci V. de Oliveira, professora doutora da UERJ, e Luciano P. da Silva, professor mestre da UNEMAT, descrevem os rituais funerários de uma região do Mato Grosso, onde há uma diversidade cultural imensa, a qual recebeu o nome de "encruzilhada de povos". Os autores do capítulo, chamado Rituais funerários na região do Pantanal de Cáceres, Mato Grosso, Brasil, depararam-se com a problemática da disparidade desses rituais funerários, em virtude da presença de diferentes tradições, as quais poderiam ter tido contatos e grandes redes de trocas naquele local. 
O resultado do conteúdo da obra confirma um pensamento bastante atual sobre a morte, pois, entre tabus e temas proibidos, como canibalismos, mortalidade infantil, esquartejamento de corpos, angústias pelo luto, é no passado que arqueólogos e historiadores procuram os embates do presente, e esse conjunto de trabalhos lembra que, para se falar da morte, há de se falar muito da vida, das culturas, da diversidade de pensamento, das expressões e do ser humano como um todo.

O que faz desse livro uma leitura especial é o fato de que os autores ressaltam que os monumentos funerários, por exemplo, expressam de uma forma ou de outra relações afetivas com os mortos, além de fazerem do cemitério um ponto de encontro e de memória. Diante dos diferentes ritos funerários, apresentados na obra, é despontado que esses locais possuem a capacidade de abranger o inconsciente coletivo e os costumes que envolvem diferentes religiosidades, filosofia, moral e política. Nesse contexto, os autores evidenciam que os registros, as artes funerárias e as fontes escritas demarcam e produzem histórias que, simplesmente, expõem o maravilhoso mundo do insondável, em lugares que perpetuam as recordações e permitem vivenciar a morte. 